\title{
The Friendly War After the War
}

\section{Well Laid Plans of British Manufacturers for Exploiting Foreign Markets \\ By David McFall}

W ${ }^{\text {HEN Great Britain threw her weight into the scale }}$ in August, 1914, not one Briton in a thousand shared Lord Kitchener's view that the war would last three years. The man in the street was so impressed by the magnitude of the conflict that its long continuation seemed to him impossible. The general optimism was reflected everywhere. Many of the London shop windows displayed a placard reading, "Business as usual during alterations to the map of Europe." A of Wales Relief Fund, contained pages for but four months. And innumerable other little manifestations reflected the same conviction.

Indeed, during the entire conflict, even when its frightful cost became apparent, the gist of every utterance was, "Business as usual." While the form of industry was changed necessarily, three-fourths of it being diverted to war work, not for a moment was the inevitable reconstruction period forgotten. It was foreseen that, whatever the disabilities imposed by the war, this period
would at the same time present greater difficulties and offer greater opportunities than were ever known before. When America entered the conflict, removing the last vestige of doubt as to its final outcome, dreams of commercial expansion were translated into actual plans. These plans are now coming to light. The linen industry These plans are now coming to light. The linen industry
of north Ireland alone has allocated to advertising purposes in America a sum approximating $\$ 200,000$. The intentions of many other great British industries are no less bold.

\section{The Federation of British Industries}

No doubt the most important step taken by British manufacturers in recent years was the formation in 1916 of the powerful Federation of British Industries. Thi organization, a direct result of new conditions and new problems brought about by the war, is made up of some fifteen thousand manufacturers and producers throughout the Kingdom, representing a combined capital of $\$ 2,000,000,000$. The Federation is professedly altruistic to the extent that it exists to further the interests of British trade generally, leaving it to each individual firm to take whatever advantage it can from the better conditions thus created.

The keynote of the Federation's task is found in a single word-publicity. The largest expenditure of money, the employment of the best talent, and fourfifths of the machinery of the organization are directed toward this end. In the singularly comprehensive publicity campaign that has been planned, and that is being put into immediate and vigorous effect, there are four outstanding features-a series of international expositions, personally conducted tours through British industrial centers, a fuller use of the moving picture film and a thoroughly organized newspaper and periodical advertising service.

\section{The British Producer and the Foreign Buyer}

Since the opening of the first international exposition in Crystal Palace, London, in 1851, Great Britain has had a greater number of successful expositions than any other one country, though to America must go the credit of having staged the largest and most attractive ones. In the matter of expositions, therefore, British manufacturers are hardly in position to instruct their American competitors. However, the Federation has adopted an attitude which is interesting and suggestive. Instead of putting on one or two large expositions, which experience has shown to be too often more attractive to pleasureseekers and curiosity hunters than to serious students of industry, it proposes a series of smaller expositions, each more conspicuous for its educational features than for anything else. The first of these will be an Anglo-Greek Exposition, to be held in London in September and October of this year. A representative of the Federation is now in Athens completing arrangements. It is understood that the event promises to be only moderately successful, as would be inferred from the povertystricken condition of Greece and her industrial backwardness.

The matter of arranging for personally conducted tours through the principal industrial centers of the Kingdom promises to be much more fruitful, as well as less costly. On April 10th a special representative of the Federation sailed for Brazil, a country with which he is familiar through long residence, empowered to extend to Brazilian importers personal invitations to visit Great Britain. During the whole of the trip the Brazilians will be the guests of the Federation. To avoid the rock on which any such educational mission is apt to split, that of favoritism in being shown certain industries to the exclusion of others, it is planned to have the itinerary cover the entire Kingdom impartially. In each industrial center the manufacturers and their organization will be invited to meet the visitors both informally and in a business way. Later, similar excursions from othe countries will be arranged for. The formation and cementing of business relationships in this way should be of lasting value. It can scarcely fail to be immediately productive, as no one in quest of trade can easily refuse it when it is sugar-coated with hospitality. The fact that the Federation has selected a South American republic for its first experiment of the kind may be rather unpleasantly suggestive to American manufacturers.

\section{Cinema Service for Manufacturers}

Perhaps the most interesting proposals-for at this stage they are mere proposals rather than accomplished facts-are those relating to a fuller use of the motionpicture film as a means of circulating information concerning British industries. Heretofore the film has been much more largely used in America than in Great Britain for showing industrial scenes and processes. The reason is obvious. Owing to America's great extent and diver sity its own inhabitants are naturally less familiar with their country than Britons are with theirs. Gatherin oranges in California or Florida, grinding cane in Louisiana, lumbering in the far Northwest, and other pursuits, are necessarily as new to the great mass of Americans a though they were carried on in foreign countries. This cannot apply within the narrow bounds of Great Britain where every form of industry, however segregated or localized, is almost within walking distance of every other. Great Britain has also labored under an irremovable disadvantage in the development and use of the film. Due to climatic conditions American films are so much sharper and clearer than British films, and therefore more pleasing, that it requires a subject of exceptional interest to create a preference for the latter. For these and other reasons the British public has accustomed itself to looking upon the film as an interesting enough amusement device, but not as one having any great educational potentialities.

One of the great tasks the Federation of British Industries has set itself is to remove the British misconception as to the value of the film, and to urge a fuller use of it. As illustrating how seriously the directorate views the problem, the following is quoted from an excellently written pamphlet, "Round the World by the Film," recently issued under its direction.

"The influence of the cinema on world-trade development is incalculable, and it should be made a great medium of national advertisement. Producers of film in this country have not been given the sane facilities for recording on the screen scenes of national life and for recording on the screen scenes of national life and
industry. Abroad, the man with the camera has been made welcome everywhere. In the United Kingdom he has been commonly treated as a nuisance or as engaged in some frivolous pastime meaning nothing to solid business men.

"Within a few years regular attendance at picture theaters has become an almost universal habit. In Great Britain there are over five hundred million patrons per annum, or twelve times the total population. It is an extraordinary anomaly that over 90 per cent of the films shown to these people are of foreign origin. What would be thought of a great country whose newspapers were 90 per cent foreign-controlled and representative of foreign mentality?"

Incidentally, the pamphlet in question pays America his emphatic compliment:

"Through the remarkable enterprise of the American cinema trade the United States is by far the best advertised country in the world. Every day millions of people all over the globe have before their eyes American scenery, American heroes and heroines, American industrial and social backgrounds, offices, factories, farms and households, and American taste in all manner of articles of trade."

In the endeavor to attain for Britain at least a part of the advantages which America now reaps so fully, the Federation makes several practical, concrete suggestions to its constituent members. Correspondence with thousands of manufacturers was invited in a circular containing the following questions:

"Are you willing to give occasional facilities at your office or your works, so that the producers of story films may avail themselves of British industrial backgrounds?
Do you make any general exception or qualification in regard to certain departments, or any limitation of time as being particularly suitable for this purpose (e.g., interesting processes of manufacture, convenient or picturesque or unique location)? Do any suggestions occur to you for giving encouragement to film producers so that the pictures throughout the world shall convey better impressions of British industry and enterprise?"

In the ordinary way, a referendum such as this would not elicit replies from more than thirty or forty per cent of the recipients, at most. But since all who receive these questions are members of the organization conducting the questionnaire, and as each member has pledged himself to support the Federation, in a large percentage of cases the questions were answered readily. The information thus gathered is being recorded and carefully classified. The Federation especially emphasizes that the information will be used impartially, in furthering industry as a whole, rather than in promoting the interests of any one manufacturer.

The method adopted to insure impartiality is interesting. It is expressly urged that in preparing a film depicting the processes of any typical industry, the entire locality in which the industry thrives should be given first consideration. Any particular industry shown will thus form but a part of the film, the historic landmarks, the modern environment and other features of the locality being given the greater attention. This provision verage spectator views a film restricted to the exclusive portrayal of a single industry, it at once occurs to him, at least subconsciously, that it is a paid-for advertisement; but when in connection with it is shown a background of picturesque or historic interest-and nearly every British industrial center has such a backgroundthe industry itself derives additional interest from its setting. At the same time, and almost in the same proportion, all of the other typical industries of the locality share in the benefits of the advertisement, even though individually they might not be suitable for pictorial representation.

The Federation has made another suggestion which is well worth acting on, that individual firms make greater use of the portable projecting apparatus by means of which their salesmen or travellers can demonstrate, in the offices of warerooms of the prospective customers themselves. It is pointed out that the requirements are quite simple-a small amount of wall space, preferably painted or papered in a light tint, and a means of electrical connectio

In view of the strength of the British Federation of Industries, and of the methodical, determined way in which British manufacturers usually carry out their undertakings, it is safe to assume that Great Britain at work will soon be figuring largely upon the screen. Indeed, it is quite likely that even American audiences will shortly be witnessing early morning processions of Manchester mill operatives with their shawls and clogs, or of the steel workers of Sheffield, or the artisans in the ugly potteries.

\section{A Larger Use of Printer's Ink}

More prosaic is the wider utilization which the Federation proposes to make of the ordinary channels of printed publicity. Some two or three years ago four separate organizations of manufacturers set up a body known as the Industrial Publicity Service, Ltd. The shares were held entirely by the participating associations, which were entitled to neither interest nor dividends, as the sole purpose of the new service was to further national, and not individual, commercial interests. As the result of an investigating committee and its recommendations, the Federation has now bought and assumed control of the Industrial Publicity Service and has taken steps greatly to widen its sphere of influence. It is proposed to make the Service yield a revenue by extending to individual firms the kind of aid rendered by ordinary advertising agencies, and charging the usual fees for such work. The whole of the revenue will be devoted to furthering the interests of the Federation.

The Industrial Publicity Service is now functioning actively in three directions. It is compiling a complete register of British industries; it is preparing technical and descriptive news matter for the foreign press; and it is preparing advertising copy for individual firms, advising as to the comparative merits of various advertising media (Continued on page 667) 
The Friendly War After the War (Continued from page 652)

and otherwise acting as orthodox adverti ing agent. It is worth noting, by the way, that those in whose hands has been placed the actual workings of the Industrial Publicity Service were selected with unusual care. They are all men of big caliber and are paid in proportion.

The supreme importance of an adequate foreign press service, as viewed by the Federation, is set forth in a report submitted by its Overseas Main Committee, dated March 5th of this year. Among other things, the report states:

Your Committee urge that propaganda and publicity matter are of special urgency at the present juncture for the following reasons:

(1) The closing down of the British Ministry of Information at a time when the governments of other countries, allied and neutral, have embarked on an intensified propaganda in overseas markets.

"(2) The great activity of foreign and publicity agents.

(3) The general lack of intelligent or adequate propaganda on behalf of British industry and commerce in the press of foreign markets, even when that press is substantially or mainly supported by revenue from the advertisements of British firms."

The man retained to control the foreign press propaganda is peculiarly well fitted for his task, having been for many years at the head of one of the largest advertising agencies in Great Britain. His staff being actively recruited, and the preparation of live news matter is at present in full swing.

It is felt by the Federation that eventually the funds accruing from the Publicity Service, in its capacity as advertising agent, will amply maintain its press service, an that these funds are more likely to increase than to diminish with the passing of the years.

Viewed by and large, in confining its definite action mainly to the sphere of publicity in its various forms, the Federation seems to have taken the only course that is both practical and impartial. Directly to subsidize, or in any other way to foster, the interests of any one industry or group of industries, could not redound to the advantage of British industry as whole.

It is quite clear that the Federation, th most powerful trade organization Great Britain has ever known, is prepared to fight to a finish for every market open to civilization. The Federation's methods in some cases have been anticipated and successfully carried out in America by the National Association of Manufacturers. In other cases the chief departure from preceden is in the comprehensiveness and thorough ness of the measures taken. At any rate American manufacturers, who are not accustomed to shrink from competition unless it be fostered by government subsidy or be otherwise unfair, need not hesitate to take up the gauntlet. It is as nearly certain as anything in the future can be that the two great English-speaking peoples are destined to hold their dominance in the world's work, and that the western hemisphere will earn its full share of the fruits of this work.

Monetary Cost of the War (Continued from page 647)

on each side. The debt of Great Britain now amounts to 36 billion dollars, of which 33 billion was incurred during the war. Thirty-six billion dollars' worth of gold would make a cube measuring 52.3 feet on a side. The debt of France is also 36 billion dollars; while Italy's debt is about 12.6 billion dollars, which would make a cube measuring 36.9 feet on a side. The gross debt of Germany is estimated at 39 billion dollars, which would make a cube measuring 53.7 feet on a side. If we pile these cubes one above the other, they would make a golden tower 254 feet high or but make a golden tower 254 feet high or but
little short of the height of Trinity Steeple in New York, which rises 284 feet from the ground.

Standing beside this tower of debt, we have shown a block of gold measuring 43.8 feet on a side which represents 20 billion dollars, or an estimated total of the supply fold in the world. Of course, the real ignificance of a debt is not measured by its total, but by the per capita burden and its relation to the income per capita of the ation. For this reason we have shown a conventional figure representing a citizen in each of the five countries involved. The wealth of the United States is estimated at 300 billion dollars and dividing this among a population of 107 million we have per capita wealth of $\$ 2,803$. The debt of 30 billion dollars divided among the same population represents a burden of $\$ 280$ on ach individual, and so the conventional figure of the American citizen is shown with a bucket which if full would hold $\$ 2,803$, but which has been emptied to the extent of $\$ 280$, while in the bottom of the bucket there is a leak from which is dripping $\$ 11.68$ representing the per capita interest on our national debt.

Great Britain is somewhat in the same ondition as the United States in the fact that a certain portion of her debt, about 5 billion dollars, will be paid back by her allies and dominions so that eventually her debt of 36 billion dollars should be reduced to 31 billion dollars, but as this has not yet been repaid we have retained the total debt of 36 billion dollars in our The per capita wealth of Great Britain is $\$ 2,608$ and her debt per capita $\$ 782$, and the interest on the debt, per capita come to $\$ 34.24$.

France with the same debt as that of Great Britain has a much bigger load to carry because her wealth is not so great and her population is smaller. In estimating the wealth of France the calculation is complicated because France suffered heavy losses of property in the war. On the other hand Alsace-Lorraine has been added to France and the wealth and income of these provinces must enter into the calculation. Taking all these factors into consideration, the national wealth of France is placed at 90 billion dollars so $\$ 2,250$ with a per capita debt of $\$ 900$ and with interest on the debt of $\$ 45$. The burden of France, therefore, is exceedingly heavy.

Italy has a debt of only 12.6 billion dollars, but her per capita wealth is only $\$ 1,111$ and her debt is $\$ 350$ per capita with interest charges of $\$ 15.22$.

Germany has a per capita wealth $\$ 1,231$ with a debt per capita of $\$ 600$ and interest charges of $\$ 30$. This, of course, does not include the indemnities which Germany will have to pay and which in turn will lighten the burdens of the other The situation is tabulated by Mr. Fisk as follows, the figures for United States having been amended by us as explained above:

DEBT AND INTEREST CHARGE COMPARED WITH ESTI-
MATED WEALTH AND INCOME OF THE PRINCIPAL BELLIGERENTS IN THE LATE WAR

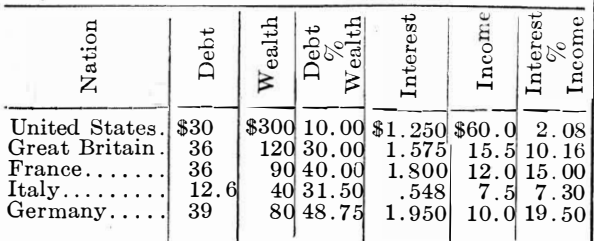

(Debt, wealth, interest and income in billions.) DEBTS AND INTEREST CHARGE COMPARED WITH EST
MATED WEALTH AND INCOME OF THE PRINCIPAL BELLIGERENTS IN THE LATE PRINCIPA

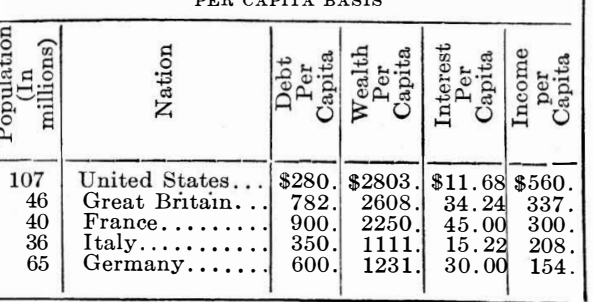

"IT IS LESS COSTLY TO BUY A GOOD BELT THAN TO SUFFER FROM A BAD ONE"

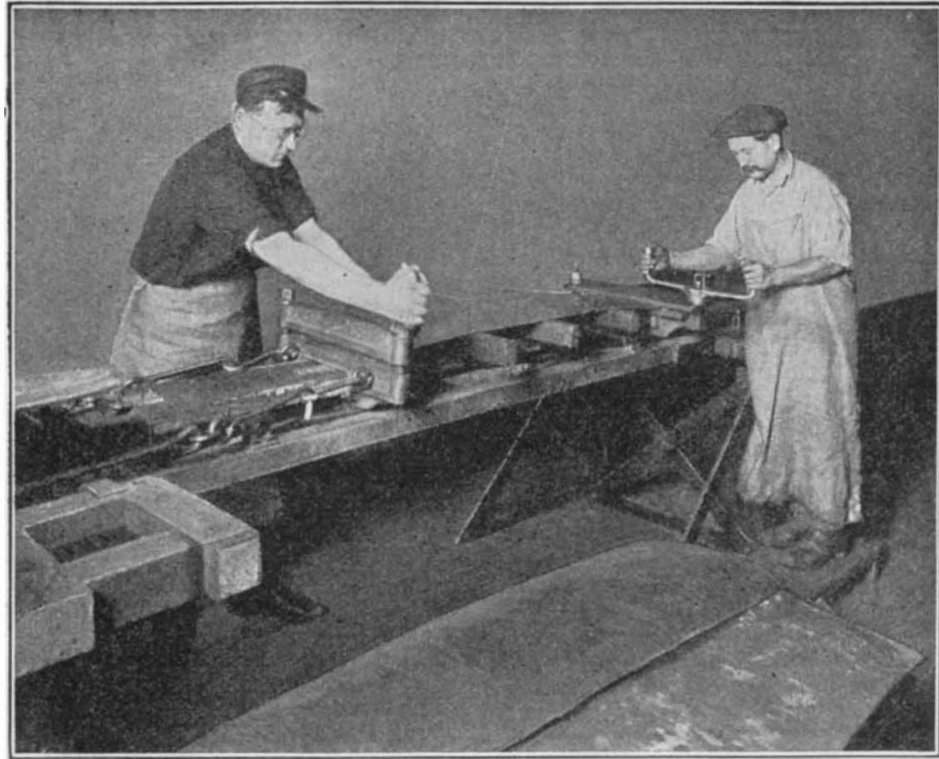

Our process of making hides into leather belting depends as fully on hand skill and experienced judgment as on machine work. This personal element in manufacture is what gives our belting its better quality. From tanning to inspection, the watchfulness and care of our workmen never stops. This accounts for the unusual wear and service of
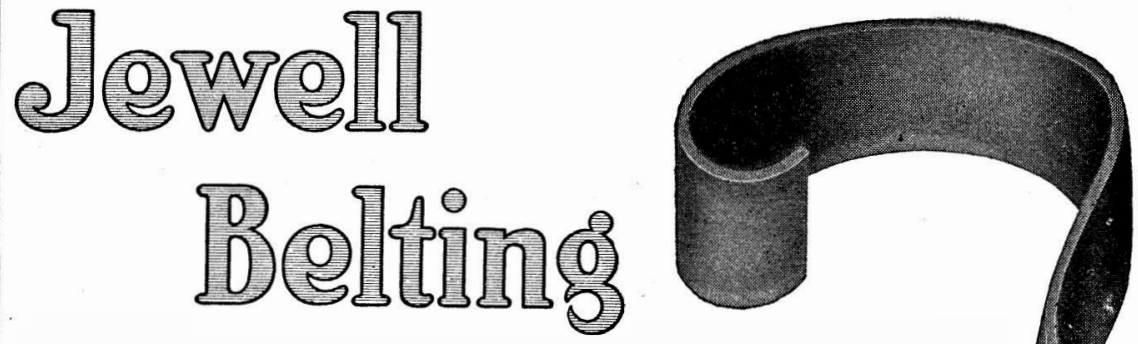

Jewell Belts are always tough, strong and pliable. They grasp power grimly, and deliver it with a will.

Whatever your belting needs, there's a Jewell Belt to suit them. Jewell experts will aid yours in picking just the right belt for your purpose.

Write us for further facts

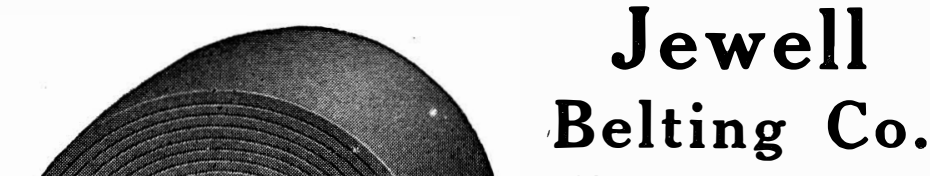

Hartford, Connecticut

Chicago Branch New York Office 2837 So. LaSalle St. $\quad 2$ Rector St. 